\title{
DEL AYUNTAMIENTO BORBÓNICO AL PRIMER MUNICIPIO CONSTITUCIONAL: EL CASO DE SANTIAGO DE COMPOSTELA ${ }^{1}$
}

\author{
MARÍA LÓPEz DIAZ \\ Universidad de Vigo
}

Tal y como se ha encargado de poner de relieve la historiografía reciente y no tanto, en España, de forma parecida a como ocurrió en el resto de Europa occidental, el Antiguo Régimen entró en crisis antes de que estallara la revolución ${ }^{2}$. En lo que atañe especificamente al régimen municipal, esta crisis es manifiesta ya durante el reinado de Carlos III y sobre todo en el de su sucesor, pero se precipitó, con el trasfondo del alzamiento nacional contra el invasor francés, a partir de 1808 por la quiebra de la monarquía absoluta y de sus tradicionales instituciones de gobierno, que se revelaron inútiles para afrontar el vacío de poder existente. Claro que la transición de un modelo (el del municipio antiguo-regimental) al otro (los ayuntamientos constitucionales) no fue automática ni tampoco drástica, pues cuanto menos un sector de las oligarquías municipales de regidores o pequeña nobleza urbana subsiste, sin solución de continuidad, en los nuevos municipios del naciente Estado liberal ${ }^{3}$. Y si a ello añadimos el examen de lo acontecido en el primer período absolutista de Fernando VII, más concre-

I. Trabajo realizado en el marco del proyecto de investigación «Sociedades y poderes: estrueturas, dinámicas y estrategias en la Galicia Meridional (1480-1850)», subvencionado por el Ministerio de Ciencia y Tecnologia, Secretaría de Estado de Política Científica y Tecnológica (BHA2003-02417).

2. Véase RUiz TORRES, Pedro: «Señorío y propiedad en la crisis del Antiguo Régimen», en DE Dios, Salustiano, Javier INFANTE, Ricardo ROBLEDO, Eugenia TORIJANO (coords.): Historia de la propiedad en España, siglos $X V-X X$ (= Encuentro Interdisciplinar, Salamanca, 3-6- de junio de 1998), Madrid, 1999, pp. 329-348 y bibliografía que cita.

3. Tal y como se ha demostrado, por ejemplo, para el caso de Murcia (PÉREZ PICAZO, M“ Teresa: «Oligarquías municipales y liberalismo en Murcia, 1750-1845», en Áreas, 6, 1985, pp. 51-74; «De regidor a cacique: las oligarquias municipales murcianas en el siglo XIX)s, en SAAVEDRA, Pegerto y Ramón ViLLARES (eds.): Señores y campesinos en la Península Ibérica, siglos XVIII-XIX, 1. Os señores da terra, Barcelona, 1991, pp. 16-37). 
tamente entre 1814 y 1815 (momento en el que se detiene este estudio), veremos que esas alteraciones del régimen municipal tampoco fueron generales ${ }^{4}$ ni muy permanentes, siendo así que la «ruptura» no se habrá de consolidar de manera definitiva hasta las décadas centrales del XIX o período 1833-1856.

Partiendo de estos presupuestos, el objeto de las siguientes páginas no es otro que analizar cómo se llevó a cabo ese tránsito de las estructuras municipales de Antiguo Régimen a la nueva planta propugnada por los constituyentes de Cádiz, no tanto desde el punto de vista legislativo y doctrinal, trabajo que ya se ha hecho ${ }^{6}$, cuanto a partir de la documentación municipal de una ciudad concreta como es Santiago de Compostela ${ }^{7}$ que a la particularidad de seguir siendo una de las poquísimas que a finales del Antiguo Régimen todavía permanecía bajo el dominio jurisdiccional de la Iglesia, añade la de ser una ciudad esencialmente absolutista ${ }^{8}$ y de los pocos municipios gallegos en los que durante la ocupación (lo fue dos veces) llegó a constituirse una administración enteramente francesa, aunque el poder real lo ejercieran otras personas (como el cabil-

4. En lo que atañe a los primeros intentos de instalación de la red municipal en Galicia (entre 1813 y 1823 ), Xosé Ramón BARReiro FernándeZ, siguiendo a FARIÑa JAMARdo (Os Concellos galegos, $10 \mathrm{tms}$, A Coruña, 1990-1993), habla de fracaso y disparidad de esta primera experiencia, pues en la provincia de Santiago sólo se constituyó en la capital mientras que en la de Tuy se habrían formado 77 . Al parecer en 1814 la propia Diputación de Galicia, al concluir su mandato, reconocía que más de la mitad de Galicia carecía de nunicipios, un balance que el mismo autor estima «excesivamente generoso» («La administración municipal en la Galicia contemporánea», en II Simposium de Historia de la Administración en Galicia, Santiago de Compostela, 1994, pp. 83-105, esp. p. 102.

5. Ya en su día lo sugería GALLEGo ANABITARTE, Alfredo: «Notas histórico-jurídicas sobre régimen local español» (Intento de revisión)», en Actas del II Symposium de Historia de la Administración, Madrid, 1971, pp. 52-54. También GuILLAMón ÁllVAREZ, Francisco J.: «Algunos presupuestos metodológicos para el estudio de la administración: el régimen municipal en el siglo XVIII», en Revista de Historia Moderna. Annales de la Universidad de Alicante, 8-9, 1990, pp. 59-74. No afecta sólo al régimen municipal. Tal y como se ha demostrado, algo parecido ocurrió en el campo de los oficios públicos enajenados (Tomás Y VALIENTE, Francisco: «Legislación liberal y legislación absolutista sobre funcionarios y sobre oficios públicos enajenados: 1810-1822》, en Actas del IV Symposium de Historia de la Administración, Madrid, 1983, pp. 703-722) y de los derechos señoriales (Hernández Montalbán, Francisco J.: «Absolutismo y crisis del régimen señorial (1814-1833)», en SARASA SÁNCHEZ, E. y E. SERRANO MARTín (eds.): Señorio y feudalismo en la Peninsula Ibérica (ss. XII-XIX), Zaragoza, 1993, II, pp. 533-566). En lo referente a la justicia, véase MARTinez PERÉz, Fernando: Entre confianza y responsabilidad. La justicia del primer constitucionalismo español (1810-1823), Madrid, 1999.

6. Vid. GaRCIA FERnÁNDEZ, Javier: El origen del municipio constitucional: autonomía y centralización en Francia y España, Madrid, 1983; y SÁNCHez-ARCilla Bernal, José: «Del municipio de Antiguo Régimen al municipio constitucional. Un caso concreto: Guadalajara», en Actas del IV Symposium de Historia de la Administración, Madrid, 1983, mayormente pp. 629-681.

7. Hay algunos casos estudiados: además de los mencionados supra, notas 3 y 6 , el de Alicante (ÁLVAREZY CAÑAS, Ma Luisa: «El gobiemo de la ciudad de Alicante en la crisis del Antiguo Régimen (1808-1814), en Revista de Historia Moderna. Annales de la Universidad de Alicante, 8-9, 1990, pp. 273-285), aunque, como señalaba $\mathrm{M}^{\mathrm{x}}$ Teresa Pérez Picazo hace más de veinte años, y creo que la afirmación sigue teniendo plena validez en la actualidad, todavía no se le ha prestado suficiente atención al tema a escala local.

8. Barreiro Fernández, Xosé Ramón: Historia Contemporánea (ss. XIX-XX). De la Guerra de Independencia al Postfranquismo (1805-1983), I, La Coruña, 1994, p. 161. 
do o la antigua corporación). Contamos para ello con un rico material conservado en el Archivo Municipal y que ahora custodia el Archivo Histórico de la Universidad de Santiago, como son lo Libros de Actas de Consistorio de estos años, incluidos los de la ocupación francesa denominados «Acuerdos del Congreso de Autoridades de Santiago», por más que tras la marcha de aquéllos estos legajos fueran recogidos y pasaran a ser custodiados por el auditor según mandato del gobernador del Reino". Igualmente contamos con los del período constitucional, a pesar de que tras la restauración el Consejo ordenó que «se borraran de los libros de Ayuntamiento las actas de elecciones constitucionales» y se tuviesen por borradas ${ }^{10}$; se entiende, a efectos legales, que no físico, pues es obvio que se conservaron.

\section{PUNTO DE PARTIDA: EL AYUNTAMIENTO DE ANTIGUO RÉGIMEN Y LA CRISIS DEL MODELO}

La configuración del ayuntamiento compostelano de Antiguo Régimen nos es bastante bien conocida igual que su evolución ${ }^{11}$. A grandes rasgos, arranca de la Baja Edad Media, en que se instauró el modelo de concejo cerrado o regimiento de impronta castellana, y se compone de un cabildo de regidores (en número variable, que pasó a lo largo de la época moderna de los diez o doce «antiguos» a veintidós a comienzos del XVIII, merced a la venta y sobre todo el acrecentamientos de oficios efectuados tanto por la Corona como por el arzobispo en su condición de señor de la ciudad), dos alcaldes ordinarios (denominados justicia) y un procurador general, teórico representante del «común» en el concejo, instituido entre finales del siglo XV y la primera mitad del XVI.

De esos veintidós regimientos, diecisiete eran renunciables y abadengos, o sea, provistos por el prelado de turno (o cabildo eclesiástico en sede vacante), y los cinco restantes perpetuos, servidos con título del rey, aunque uno había sido creado por el titular del señorío y los otros cuatro con su consentimiento. En cuanto a las otras dos instancias municipales correspondían a cargos electivos y anuales: en el caso de los alcaldes ordinarios la elección se hacía por el sistema de cobrados (propuesta de doce candidatos por parte del regimiento y selección final del arzobispo) y en el del procurador general competía al pueblo, resultando elegido aquél que obtenía mayor número de votos. En el transcurso de la segunda mitad del XVII, sin embargo, dicha elección deja de ser abierta, pues los candidatos van a ser propuestos por el concejo, y a partir de

9. Archivo Histórico de la Universidad de Santiago (en adelante, AHUS): Sección Municipal, Libros de Consistorio (o LdC) 1809, n 311 , Consistorio (o CO) 30/9/1809, f. 342.

10. Real Cédula de 25 de junio de 1814, publicada en la Gaceta del Gobierno de martes, 5 de julio de 1814 (Ibidem, LdC de 1814, $\mathrm{n}^{\circ} 325, \mathrm{CO} 21 / 8 / 1814$, ff. 647-647v y 665-667).

11. López DiAz, María: Gobierno y hacienda municipales. Los concejos de Santiago y Lugo (siglos XVI$X V I I)$, Lugo, 1996. En lo que atañe al crecimiento del número de oficios, desde una perspectiva comparada: «Enajenación de oficios y gobierno de los pueblos: las ciudades gallegas en el siglo XVII», en ARANDA PÉREZ, Francisco (coord.): La declinación de la Monarquía Hispánica en el siglo XVII, Cuenca, 2004, pp. $721-738$. 
1765-66 deja de ser además directa, haciéndose desde entonces mediante compromisarios (dos por cada una de las once parroquias que integraban la ciudad).

A tenor de todo ello, especialmente de la condición y sistema de acceso, el gobierno ciudadano fue adquiriendo un tono y modos cada vez más oligárquicos, debido a la intromisión de ciertos sectores nobiliarios en los resortes del poder municipal. Este régimen oligárquico se consolida, con el respaldo señorial, mediante la «renuncia» que permite la transmisión de los oficios de regidor por vía hereditaria y, posteriormente, se afianza con la concesión de algunos de los nuevamente creados a perpetuidad. Siendo así que a comienzos del XVIII unos y otros estaban patrimonializados y la mayoría vinculados a familias de rango, en tanto que la provisión de los cargos electivos era en gran medida «controlada» por esas mismas familias que conformaban una «oligarquía dirigente» relativamente cerrada (aunque no exenta de renovación ${ }^{12}$ ), esencialmente nobiliaria (pero con algunos elementos burgueses), parasitaria (pues la mayoría son rentistas) y bien instalada en su posición de predominio sobre el resto de los ciudadanos.

Con la entronización de la nueva dinastía borbónica el panorama no varió sustancialmente, pese a algunos intentos que los primeros monarcas llevaron a cabo pretendiendo revisar las regalías enajenadas (los oficios municipales entre ellas) y poner coto a esa patrimonialización de los oficios (mayormente perpetuos) que era vista como un grave perjuicio para el «buen gobierno» de los pueblos ${ }^{13}$. De hecho, lo más que hicieron fue parchear la situación con medidas parciales $o$ «específicas» que procuraban subsanar problemas o aspectos concretos. En el caso que nos ocupa, por ejemplo, en 1713, aprovechando las disputas y divergencias internas de los grupos dirigentes locales, que rebrotaron con fuerza en el transcurso de la primera mitad del XVIII, el Consejo de Castilla -que era el principal responsable de recortar las competencias municipales- prohibió a los titulares o dueños de oficios que los ejercían personalmente nombrar tenientes o sustitutos, aunque tuvieran prerrogativa para ello, y ordenó que quienes así los estuvieran usando quedasen en suspenso hasta que la propiedad del cargo pasase por título legítimo a manos de otra persona (la medida afectó también a las otros concejos urbanos gallegos). Igualmente, despachó una segunda provisión, en su caso a instancias del titular de un regimiento a quien la corporación se negaba a recibir so pretexto de ciertas incompatibilidades, inhibiendo a la Real Audiencia de Galicia de dicho asunto así como de todos los demás concernientes a regidores y arbitrios de la ciudad, reservándose dicho conocimiento privativamente. Claro que esta disposición sólo tuvo vigencia durante unos pocos años, pues en la década siguiente el tribunal

12. Idem: «Dinámica de una oligarquía urbana: el cabildo de regidores compostelano durante los reinados de Felipe IIl, Felipe IV y Carlos II», en Minius, XIV, 2006, pp. 165-178.

13. En lo referente a la trayectoria y principales avatares de la institución municipal y sus gobernantes durante el XVIII, resumimos algunas de las conclusiones de nuestro trabajo: «Reformismo borbónico y gobierno municipal (las regidurías compostelanas, siglo XVIII)», en Obradoiro de Historia Moderna, 15,2006 , pp. $205-237$. 
gallego ya aparece conociendo de las causas de los regidores compostelanos en tanto que la inhibición de los arbitrios se deroga en 1729.

En cuanto a la dinámica interna de ese grupo de poder que es la oligarquía dirigente, continúa el cierre y se afianza su carácter aristocrático, hasta el punto de que en 1743 el consistorio decide por mayoría solicitar el estatuto de nobleza para la ciudad. Formalmente no lo consiguió, pero en la práctica el acceso al concejo para los plebeyos se fue haciendo cada vez más difícil, dado que entonces casi todos los oficios de regidor (incluidos los renunciables) estaban ya vinculados, siendo las entradas restringidas y «controladas» desde dentro por el propio grupo. Simultáneamente, se fue agravando y hace preocupante el problema del absentismo capitular; y no sólo porque empiecen a quedar oficios vacantes (aquéllos en los que sus dueños no presentaban las credenciales necesarias para ejercerlos, algo que en los siglos precedentes sólo había ocurrido de manera excepcional), sino, lo más grave, por el desinterés y reiterada inasistencia de los ediles titulados a los consistorios. De nada sirvieron las continuas quejas y protestas de los munícipes asistentes, ni tampoco los requerimientos y órdenes de la Real Audiencia contra una corrupción cada vez más evidente.

Llegamos así al reinado de Carlos III que se sitúa en un momento crucial del final del Antiguo Régimen, donde a los anteriores problemas (algunos empeoran) se van a añadir otros nuevos. En primer lugar, las dos figuras institucionales ideadas por Campomanes y creadas en 1766 (procurador sindico personero y diputados del común), igual que ocurrió en otras localidades, no fueron bien acogidas por los dirigentes municipales. De hecho, se demora tanto la aplicación de la Instrucción como la celebración de elecciones. Incluso después de instauradas hubieron de sortear numerosas dificultades para asentarse, al tiempo que aumentan las tensiones y conflictos de competencia entre quienes ocupaban dichos oficios y los regidores u oligarquía tradicional, sobre todo a partir de 1780 cuando empiezan a salir electos como tales miembros de la burguesía adinerada que se quejan de tener poca capacidad de maniobra frente a aquéllos ${ }^{14}$.

14. Ibidem. Véase además Cebreiros Alvarez, Eduardo: El municipio de Santiago de Compostela a finales del Antiguo Régimen (1759-1812), Santiago de Compostela, 1999, pp. 252-254; y en lo que atañe a la oposición que las nuevas instituciones suscitaron en otras poblaciones: INFANTE MIGUEL-MOTTA, Javier: El municipio de Salamanca a finales del Antiguo Régimen, Salamanca, 1984, pp. 97-99; CuESTA MARTINEz, Manuel: Oficios públicos y sociedad. Administración urbana y relaciones de poder en la Córdoba de finales del Antiguo Régimen, Córdoba, 1997, pp. 347-348; Romero MatEo, M" Cruz: Realengo y municipio: marco de formación de una burguesía (Alcoi en el siglo XVIII), Alicante, 1986, pp. 103-105; GUILLAMÓN AlVÁREZ, Francisco Javier: «Tensiones en el municipio de Bilbao en la segunda mitad del siglo XVIIl», en Cuadernos de Investigación Histórica, 4, 1980, pp. 153-165; NOREÑA y SALTO, M" Teresa y NÚNEEZ PESTANO, Juan Ramón: «Reformismo y reacción en la administración Jocal. Los conflictos entre el personero Carlos Soler Carreño y la oligarquía concejil de Tenerife (1786-1790)》), en Coloquio Internacional de Carlos III y su siglo, II, Madrid, 1999, pp. 444-466. Bien entendido que no siempre sucedió esto, pues hubo localidades donde los nuevos oficios apoyaron e incluso tuvieron complicidad con los oligarcas locales, reforzando aún más su dominio y control. Y es que, como en su día señaló GuILLAMÓn ÁlVAREZ, la reforma municipal de 1766 fue un proceso desigual en sus ritmos, variable en sus acciones y con logros igualmente muy desiguales («Reformismo institucional y gobierno 
Igualmente, dentro del consistorio el absentismo capitular se hace preocupante al tiempo que se produce un sensible aumento de las vacantes, siendo así que a veces ni siquiera se lograba reunir el «número necesario [de ediles] para el régimen económico de la ciudad». El problema fue lo suficientemente grave como para que en el año 1787 se denunciara extrajudicialmente ante la Cámara de Castilla, quien ordenó al concejo remitir un informe completo de los regimientos que había en la ciudad y cuál era su estado, señalando además término de dos meses a los propietarios de oficios «vacos» para que obtuviesen el título correspondiente. No sirvió de nada: las quejas continúan y lo mismo ocurre en el resto de los concejos urbanos de Galicia. Es por ello que en 1792 se trata el asunto en una sesión de la Junta del Reino, proponiendo sus diputados, como remedio, que los regidores fuesen vecinos de sus respectivos municipios y que se les otorgase un máximo de dos meses para tomar posesión del cargo, no gozando de derechos quienes no cumplieran las comisiones municipales repartidas por turno. Ni que decir tiene que era una medida -en realidad, una recomendación- harto difícil de aplicar, que tampoco surtió efecto, pues los oficios estaban patrimonializados y sus dueños disponían de ellos como de un bien sustantivo.

Durante estos años también empeoran las relaciones de esa minoría dirigente con su señor, el arzobispo, pues van a estar salpicadas de tensiones. De hecho, rebrota la conflictividad antiseñorial, que a veces se entremezcla con la que internamente existía desde la primera mitad de siglo dentro del consistorio, aunque la ligazón entre ambas tiende a ser cada vez menor ${ }^{15}$. Para paliar precisamente esta conflictividad, en $1752 \mathrm{el}$ conde de Itre, gobernador y capitán general del Reino, ya recomendara al arzobispo Rajoy la instauración de un corregidor forastero, letrado, trienal y sometido a residencia, que administrase justicia en vez de los dos alcaldes ordinarios existentes. Incluso presentó el proyecto ante el Consejo de Castilla, donde se negoció con los co-depositarios del señorío, pero las gestiones fracasaron porque la propuesta de los interlocutores catedralicios dejaba poco margen de maniobra o no interesaba al poder real. Se volvió sobre el asunto en otras tres ocasiones: una en 1761, por iniciativa de la ciudad que lo consideraba un paso hacia su incorporación al realengo, un viejo anhelo; otra diez años más tarde, promovida asimismo por Rajoy como reacción frente a la «osadía e insolencia» con la que procedían las autoridades municipales frente a algunos de sus proyectos; y la tercera a fines de 1782, a instancias del cabildo eclesiástico que reenvía la propuesta a la alta Cámara, pretendiendo así acabar con la negligencia y parcialidad

municipal en el siglo XVIIl», en Alvar EzQuerra, Alfredo, De Bernardo Ares, José M. y MOLAS RIBALTA, Pere (coords.): Espacios urbanos, mundos ciudadanos: España y Holanda (ss. XVI-XVIII): Actas del VI Coloquio Hispano-Holandés de Historiadores celebrado en Barcelona en noviembre de 1995, Córdoba, 1998, pp. 65-82).

15. Dado que ésta tiende a polarizarse entre facciones o luchas de bandos de nuevo reanimadas, primero, y entre instancias tradicionales (justicia y regimiento) e instancias nuevas (diputados y personero del comin), después. Para análisis y más detalle, LÓPEz DíAZ, María: Reformismo borbónico, op. cit., pp. 223-227. Ocurre también en otras localidades; véase, al efecto, PErez PICAZO, Ma Teresa: Oligarquias municipales, op. cit., pp. 58-62. 
con la que se comportaban los munícipes, a lo que el gobernador respondió que el expediente no podía resolverse mientras la sede estuviera vacante ${ }^{16}$. Posiblemente, el concejo no fue del todo ajeno a dicha resolución, pues quienes lo dominaban (regidores y oligarquía tradicional), tras la creación de los nuevos oficios electivos, que fue algo así como una primera alerta de lo que podía suceder si el control de la corporación se les escapaba de las manos, eran plenamente conscientes del perjuicio que podría ocasionarles la implantación de un corregidor en vez de los dos alcaldes ordinarios cuya elección mediatizaban, sobre todo si aquél era de designación real.

En estas circunstancias la situación si no se agravó tampoco mejoró. Prueba de ello es que apenas transcurridos dos años, en 1786, la recién creada Sociedad Económica de Amigos del País de Santiago presentaba un escrito ante el cabildo eclesiástico, solicitándole que pusiese remedio al desorden y males que aquejaban a la ciudad por la falta de justicia que se constataba en ella ${ }^{17}$. Para entonces la sede ya tenía dueño, por lo que cabía pensar en algún tipo de medida. Pero a su nuevo titular, fray Sebastián Malvar y Pinto, no le preocupaba demasiado este asunto, pues tenía otras prioridades. Así es que durante los años posteriores continúan las disputas y animadversión entre ambos poderes.

Estos son algunos de los indicios o signos de agotamiento y «crisis» del modelo municipal de Antiguo Régimen así como del sistema que lo sustenta, unos signos que tras la muerte de Carlos III y sobre todo en la década finisecular y primeros años del XIX se van a hacer cada vez más evidentes, al compás de lo que el profesor Ruiz Torres ha denominado «una política contradictoria en una época de contradicciones sociales» a las que el reformismo ya no podía dar respuesta ${ }^{18}$.

En lo que atañe por ejemplo a los diputados y síndico personero, como no conllevaban fermentos revolucionarios, van a sobrevivir a la reacción que después de 1789 encabezó Floridablanca tratando de prevenir contagios revolucionarios, pero se frenaron sus expectativas de ampliar competencias con la complicidad del poder real. Así, en septiembre del año 1788 el Real Acuerdo ordenaba a los alcaldes compostelanos que no convocasen ningún consistorio sin llamar previamente a los diputados del común ${ }^{19}$. Pues bien, al cabo de dos meses éstos todavía seguían pidiendo que se cumpliera dicha real provisión ${ }^{20}$ y en enero del año siguiente protestaban porque no se les había permitido votar en las elecciones de oficios y se incumplía la disposición de la

16. LOPEz Ferreiro, Antonio: Fueros municipales de Santiago y de su tierra, Madrid, 1975 (edición facsímil de la de Santiago, 1895), pp. 627-633; Historia de la Santa A. M. Iglesia de Santiago de Compostela, Xunta de Galicia (edición facsímil de la de Santiago de Compostela, 1911), I-XI, csp. tm. XI, pp. 3738.

17. Ibidem, pp. 38-39.

18. RIZ Torres, Pedro: «La crisis municipal como exponente de la crisis social valenciana a finales del siglo XVIll», Estudis, 3, Valencia, 1974, 167-197, esp. 179.

19. AHUS: Municipal, LdC 1788, n²66, CO 3/10/1788, ff. 166v-167; también López Flrreiro, Antonio: Fueros municipales, op. cit., p. 623.

20. AHUS: Municipal, LdC 1788, CO 16/12/, ff. 251v-252. 
Audiencia de Galicia ${ }^{2 !}$. Incluso recurrieron a dicho tribunal, pero, sorprendentemente, ahora el Acuerdo dictó un auto precisando que sólo podían asistir a reuniones sobre abastos y caudales públicos y a todas las que tuviesen interés para el público o pudiesen perjudicarles ${ }^{22}$, con lo cual corrigió los términos generales de lo que había dispuesto un año antes. En 1793, posiblemente al amparo del nuevo gobierno o de tiempos más revueltos, aquéllos vuelven a intentarlo: para ello iniciaron acciones legales en el mismo tribunal, en su caso para lograr el reconocimiento a participar en las elecciones de alcaldes ordinarios (elaboración de cobrados), tenientes coroneles de milicias, comisarios de millones, etc. Pero la resolución del alto tribunal volvió a ser tajante, dictaminando que no tenían voz ni voto en las mencionadas elecciones ni tampoco en los demás actos «privativos» de la ciudad ${ }^{23}$.

Tampoco parecen haber mejorado las cosas en lo tocante a la asistencia. Hay, sin embargo, una novedad con respecto a las décadas precedentes en la forma de afrontar el problema desde el concejo: aparentemente cesan las quejas ante los órganos e instancias superiores, quizás por miedo o temor a que éstos adoptasen medidas drásticas en un momento en que las exigencias hacia los ayuntamientos eran cada vez mayores y más urgentes. Incluso cuando se les requiere información al respecto procuran ocultar o maquillar la realidad. Posiblemente, con ello trataban de preservar su posición, máxime en unos tiempos que se tornan cada vez más revueltos y difíciles. $Y$ en el mismo sentido cabe interpretar la férrea oposición del regimiento frente a los intentos del conde de Altamira por reactivar -mejor habría que decir activar, pues nunca se usó- el oficio de regidor que Felipe IV concediera al conde duque de Olivares en la ciudad como una de las que tenía voto en Cortes. En su caso con éxito, pues continuó desactivo, dado que el entonces titular de la Casa (los Altamira) ya disponía de otras dos regidurías en ella (una renunciable y otra perpetua).

Igualmente, son notorios los intentos del grupo dirigente por proteger y reforzar su posición dentro del ayuntamiento: no en vano las tres cuartas partes de las regidurías eran renunciables y de provisión episcopal; o sea, que sus dueños no tenían sobre ellas la plena disponibilidad. Como es lógico, su deseo era convertirlos en reales y perpetuos. De ahí que en 1782 la corporación elevara una representación al Consejo de Castilia, solicitando el establecimiento de regimientos reales en todas las ciudades de voto en Cortes, apelando para ello a los perjuicios que les deparaba el que fuesen de abadengo ${ }^{24}$. La iniciativa no prosperó, por lo que vuelven a intentarlo seis años después: en esta ocasión en una Junta del Reino, donde el diputado compostelano Francisco Taboada y Gil llama la atención sobre la inestabilidad de las regidurías renunciables de la ciudad por tenerse que renunciar semanalmente, una formalidad que hacía que a veces se «perdiese» 0 «colase» el oficio y fuese provisto directamente por

21. Ibidem, LdC $1789, n^{\circ} 267$, CO 3/1/1789, ff. $4 \mathrm{v}$ y $18-18 \mathrm{v}$.

22. Ibidem, CO 29/5/1789, ff. 312 y $307-307 \mathrm{v}$.

23. Ibidem, LdC 1794, n"277, CO 14/2/1794, f. 93.

24. Ibidem, LdC 1782, n² 251, CO 19/2/1782, ff. 86-86v. 
el prelado. Pidió que la mencionada asamblea enviara una representación a la Cámara de Castilla con el fin de que se fijara la propiedad de dichos oficios «a perpetuidad» en las Casas que ya los poseían ${ }^{25}$. Cosa que aquélla hizo, dando cuenta del grave perjuicio que la mencionada situación causaba también en las otras tres ciudades episcopales del Reino, pero la gestión no fructificó. Como tampoco lo haría en 1794, cuando la misma Junta reitera su demanda, añadiendo que únicamente deberían revertir los oficios a los prelados en el supuesto de demencia o inexistencia de sucesores legítimos del posee$\operatorname{dor}^{26}$.

En lo que atañe a la sociología de los regidores de estos años, lo más destacable es que, a diferencia de lo que ocurre en otras ciudades, no se constata en Santiago un retorno de la alta nobleza a la política activa ${ }^{27}$ : en realidad, aquí nunca estuvo presente, pues sólo ejerció el cargo excepcionalmente (conde de Altamira) o para determinadas comisiones (procuraduría en Cortes); y del resto de los regidores con título nobiliar que sí lo desempeñaron sólo uno viene del setecientos, los otros lo obtuvieron en el transcurso del XVIII, siendo su procedencia diversa. Igualmente, consolidaron su posición aquellos linajes que habían ingresado de nuevo en el regimiento durante la última centuria, la mayoría de origen burgués. Aun así, el protagonismo indiscutible sigue correspondiendo a la hidalguía y baja nobleza local o provincial, que acredita procedencias diversas. Entre ellos se cuentan algunos apellidos de lustre pero exógenos (familias oriundas o enraizadas en otras ciudades, mayormente Coruña) y también conocidos personajes de la Ilustración gallega ${ }^{28}$. Ni que decir tiene que son ilustrados moderados, que tratan de conciliar esas ideas renovadoras con el respeto al sistema constituido, al que además sirven (y no sólo como regidores) y del que obtienen privilegios. Es más, cuando los ven amenazados por alguna razón o que peligra su posición dentro del mismo reaccionan, adoptando una postura claramente conservadora.

En este sentido, es elocuente la propuesta que en el año 1804 hace el regimiento en un informe que elabora a pedimento del Real Acuerdo y Consejo de Castilla sobre el arraigo de sus regidores. Después de referir los inconvenientes del cargo (el principal: que no tenían dotación alguna y que su desempeño sería «insoportable» para quien

25. Sesiones de 30 de abril y 24 de mayo de 1788 (FERNÁNDEZ-VILLAMIL, Enrique: Juntas del Reino de Galicia, Madrid, 1962, II, pp. 51-52).

26. ARTAZA, Manuel María de: A Xunta do Reino de Galicia no final do Antigo Réxime (1775-1834), La Coruña, 1993, pp. 103-104, donde se hace eco también de lo anterior.

27. Cfr. Villas TinoCo, Siro: «Poder y poderes en la ciudad del Antiguo Régimen», en Baetica. Estudios de Arte, Geografia e Historia, 21, 1999, p. 373; y «Andalucía en el tránsito a al Edad Contemporánea», en Baetica. Estudios de Arte, Geografia e Historia, 20, 1998, pp. 406-407.

28. Caso de los coruñeses José Francisco Cornide y Folgueira y de Antonio Vicente Zuazo de Mondragón y Ron, marqués de Almeiras, dueño del complejo textil de Sada; pero también del doctor José Somoza Osorio Suárez de Lobera, catedrático de prima cánones de la Universidad de Santiago, Juan Francisco Javier Somoza y Ulloa, teniente coronel de los ejércitos de la ciudad compostelana, conocido por sus traducciones de algunas obras francesas, o Juan Cisneros Sarmiento y Ulloa, conde de Gimonde. Y seguramente no eran los únicos: no en vano se creó la Sociedad Económica de Amigos del País en la ciudad en el año 1784 con el respaldo y una nutrida representación de la clase política local. 
careciese de rentas suficientes), añaden que les parecía «que devieran tener algún tratamiento y distinción más», pues de todos los empleos de gobierno de la Monarquía el de regidor en el Reino de Galicia se servía sin el menor estipendio, desempeñando muchas y graves comisiones del real servicio y bien de la comunidad con total desinterés. No sin recordar que quienes lo ejercían ya eran y siempre habian sido «sugetos de notorio arraigo y nobleza principal del Reyno» ${ }^{29}$. Es obvio el cambio respecto a las reivindicaciones formuladas en la década de 1780: entonces se pedían la perpetuidad de los cargos; ahora, a comienzos del XIX, dado el rechazo cada vez mayor que suscitan los oficios perpetuos ${ }^{30}$, ciertas distinciones, indirectamente quizás la nobleza preceptiva, ya fuese por intereses de clase o porque consideraban que la sociedad precisaba del soporte nobiliar que no debía ser debilitado. Con todo, lo que más sorprende es que los diputados y el personero del común avalan la propuesta, estimando «de necesidad deverse servir (dichos cargos) por sugetos de calificada conducta y avono para responder a las obligaciones propias de su empleo, y a fin de evitar operaciones iregulares que serian temibles si recaisen en sugetos yndigentes», lo que pone de relieve el potencial «revolucionario» de los pobres e indigentes que vagan por la ciudad. Acaso por el propio contexto de crispación, pobreza y malestar social de estos años que se intuye como detonante de la propuesta.

Otro tanto puede decirse de la airada y contundente respuesta de la oligarquía municipal frente a una curiosa representación que el también ilustrado y polémico Juan José Caamaño y Pardo, conde de Maceda, envió a finales de 1801 a Godoy, donde recomendaba la implantación en la ciudad de un «gobernador político militar» en vez de los dos alcaldes ordinarios y las dos justicias señoriales (asistente y juez ordinario de la quintana). Todo con el fin de acabar con «la relaxación de costumbres» y deficiente administración de justicia, que, según él, había en la ciudad, como consecuencia de la existencia de numerosos jueces que no cumplían con su cometido y que además entraban en competencia entre ellos ${ }^{31}$. Pues bien, cuando el concejo tuvo conocimiento de dicho escrito y fue requerido por ello, sus dirigentes lo tildan de falso, infame,

29. AHUS: Municipal, LdC 1804, CO 30/10/1804, ff. 225-225v (el subrayado es mío).

30. En el plano doctrinal destaca el ilustrado vasco José Agustín IBÁÑEZ DE LA RENTERi̊ y su Discurso sobre el gobicrno municipal, publicado como apéndice por Mariano BAENA DLL ALCÁZAR: Los esfudios de la Administración en la España del siglo XVIII, Instituto de Estudios Políticos, Madrid, 1968, pp. 113-149, pronunciado en 1783. La edición completa de los cuatro Discursos es de la Imprenta de D. Pantaleón Aznar, Madrid, 1797.

31. AHUS, Municipal, LdC 1802, CO 22/1/1802, ff. 43-57. Extracta algunos de los párrafos de esta representación MEijde PARDo, Antonio: Juan José Caamaño y Pardo (1761-1819), Conde de Maceda, Illustrado y Economista Ferrolano, A Coruña, 2001, p. 26. Otros ilustrados gallegos ya habían llamado la atención antes de este problema que solía darse en el Reino como consecuencia del predominio señorial y de sus consecuencias, caso de HERBELLA DE PUGA, aunque su propuesta es otra: él defiende la retrocesión de la jurisdicción cedida en siglos anteriores a la monarquía e implantación de corregimientos (Discurso sobre la necesidad de que se establezcan corregimientos en el Reino de Galicia, Santiago, 1767). Caamaño y Pardo constata la situación, pero -nótese-en ningún caso pide o plantea la supresión del sistema señorial, sino la instauración o añadido de una nueva institución. 
temerario e incluso monstruoso (de hecho, se pide que sea quemado en la plaza pública como libelo infamatorio), al tiempo que defienden la condición abadenga de la ciudad, restando importancia a esta circunstancia, pues, precisaban, las justicias señoriales juzgan por la ley real y su jurisdicción aunque se denominaba así (abadenga o señorial) emanaba toda del rey.

Paradójicamente, a finales del año 1804 o principios del 1805 son esas mismas autoridades municipales quienes presentan ante el Consejo de Castilla un memorial en el que denuncian los abusos de los tribunales y justicias señoriales, solicitando que se suprimieran y dejara sólo a los dos alcaldes ordinarios (justicia municipal) $)^{32}$, lo que de producirse habría precipitado el fin del señorío episcopal. En estrecha relación con ello, en junio de 1802 se había aprobado una disposición general que trataba de regular el nombramiento y salario de los alcaldes mayores de señorío, pues «por ahorrar sueldos de dependientes, y conservar las antiguas miserables dotaciones..., [los señores] reunen en una persona este ministerio con el de administradores de sus rentas y estados» ${ }^{33}$. No afecta especialmente al prelado compostelano, pues desde la segunda mitad del XVI ya designaba como justicias señoriales (alcalde mayor o asistente y el juez de la quintana) a letrados seglares, con retribución expresa y además estaban sometidos a residencia ${ }^{34}$. No obstante, sí pudo favorecer la mencionada denuncia, dado que los nominados solían ser dependientes o personas del entorno del mitrado de turno. Es, precisamente, esta última circunstancia, unido al desorden y empeoramiento de las condiciones de vida en la ciudad por la afluencia de pobres y desarraigados, lo que hace que surjan conflictos de competencia entre dichas justicias, sobre todo el asistente, y la corporación municipal ${ }^{35}$.

Sea como fuere, en este contexto recobra fuerza la denuncia efectuada por Caamaño ante el mismo organismo, quien comisiona de nuevo al Real Acuerdo para que informe sobre el asunto. Incluso se emplaza al cabildo eclesiástico, mientras en las altas instancias ambas partes se cruzan duras acusaciones y buscan todos los apoyos posibles para su respectiva causa. Forma parte de lo que López Ferreiro denominó, no exento de interés, una «conspiración» en toda regla del ayuntamiento contra le señorío episcopal, que concluye a principios de 1807 con el sobreseimiento del proceso. Claramente, los acontecimientos políticos que sobrevinieron en la Corte, unido a las grandes presiones que allí se entrecruzaron acabaron favoreciendo al arzobispo, pues

32. Da cucnta del asunto, partiendo de las actas del cabildo eclesiástico, LOPEZ FERREIRO, Antonio: /4istorita. op. cit, XI, 121-123. No nos consta referencia alguna en la documentación municipal hasta 1806, y aun entonces muy vaga (AHUS: Municipal, LdC 1806, CO 3///1806, ff. 8-9).

33. Novisima Recopilación, VII, 11,32. Sobre los abusos y quejas de la justicia señorial, véase DominkiUl:z OrTiz, Antonio: Sociedad y Estado en el siglo XVIII español, Barcelona, 1976, pp. 4344435.

34. LOPLz DiAz, María: Señorio y municipalidad. Concurrencia y confficto de poderes en la cinadad de Santiago (siglos XVI-XVII), Santiago de Compostela, 1997, pp. 230-242.

35. AHUS: Municipal, LdC 1804, n²97, CO 7/2/1804, f. 70: Querella contra el juez asistente por rondar; CO 9/2/1804, f. 75; CO 14/4/1804, f. $213 ; n^{\circ} 298, \mathrm{CO} 24 / 11 / 1804$, f. 285; LdC 1805, n 299, CO $5 / 4 / 1805$, etc. 
conservó el dominio sobre la ciudad, aunque las relaciones entre ambos poderes quedaron muy deterioradas. De hecho, en los meses que siguen continúan las fricciones y no será hasta finales de año cuando se «pacifiquen» definitivamente las cosas.

Aun así, es obvio que a estas alturas la institución señorial ya estaba moribunda. Lo que acabamos de referir son sólo algunos de los síntomas de esa crisis que le afecta $\mathrm{o}$, si se prefiere, los últimos estertores de la misma, previos a la disolución de ese centenario vínculo que traerá consigo el régimen liberal.

Algo parecido ocurre en el caso de la institución municipal y su clase política. Continúa el desinterés por ejercer los oficios tradicionales, sobre todo los electivos. Concretamente, en los bancos del regimiento hay varios vacantes (prueba de la ineficacia de las disposiciones y requerimientos de los años 1780-90), cada vez son menos los dueños de oficios que se acreditan para ejercerlos, continúa el problema del absentismo y existe una menor movilidad o renovación de personas (pues la de familias ya es prácticamente nula). Así, según el borrador de un informe elaborado en 1812 por el concejo a instancias del Real Acuerdo ${ }^{36}$, de los veintidós cargos que componían el cabildo de regidores cinco estaban vacantes $(23 \%$ ) y diecisiete activos (cuatro perpetuos y trece renunciables de provisión arzobispal), aunque realmente solo se desempeñaban (con asistencia diversa) diez, es decir, menos de la mitad de la plantilla (45'5\%). De esos diecisiete cargos activos sólo en ocho casos el titular «con uso» era el propietario o dueño del mismo (esto es, un $47 \%$ de los mismos; el $37 \%$ de toda la planta cuando a mediados del XVIII ese porcentaje era del $55-60 \%$ ), mientras que en los nueve restantes el oficio figura cedido a tenientes o personas de su entorno personal o familiar. Por su parte, en el caso de los viejos cargos electivos (alcaldías ordinarias y procuraduría general) durante la década finisecular y primeros años del XIX proliferan las excusas y disculpas de los electos para ejercerlos, sobre todo si son nobles que eran partidarios de los privilegios por nacimiento. La corporación suele desoírlas, lo que no impidió las incomparecencias, siendo así que a veces la corporación incoa expediente ante la Real Audiencia para «obligarles» a aceptar ${ }^{37}$.

Por lo que sabemos de los nuevos cargos creados en 1766 (diputados y síndico personero del común) la oligarquía dirigente no logró controlarlos, cuanto menos en la medida deseada, y la causa de esa imposibilidad radicaba en el sistema electoral. Por eso atacó el proceso y, como hizo alguna otra localidad, no dudó en proponer uno que le permitiera seleccionar a las personas que habrían de optar al cargo ${ }^{38}$. Ocurre en 1808, en el informe que elaboró a pedimento del Real Acuerdo, conforme a una orden del Consejo de Castilla, sobre la necesidad de fijar un procedimiento justo para las

36. Lbidem, LdC 1812, n 319 , ff. $434 \mathrm{v}-435$.

37. Ibidem, LdC 1802, n²91, CO 12/1/1802, f. 28; CO 15/1/1802, f. 37; LdC 1803, n² 294, CO 1/1/1803; CO 15/1/1803; LdC 1805, n' 299, CO 12/1/1805; n 301, CO 19/12/1805; LdC 1806, n² 302, CO 1/1/1806; $\mathrm{LdC} 1807, n^{\circ} 304, \mathrm{CO} 30 / 12 / 1807$; LdC 1808, $\mathrm{n}^{\circ} 306, \mathrm{CO} 1 / 1 / 1808$; CO 9/1/1808, etc.

38. Caso de Valencia, que en el año 1805 pidió que se emplease el sistema insaculatorio (IRLÉs VICENTE, $\mathrm{M}^{3:}$ Carmen: El régimen municipal valenciano en el siglo XVIIT. Estudio institucional, Alicante, 1995, pp. 218-219). 
mencionadas elecciones, con el fin de acabar con los abusos y fraudes denunciados. El concejo comisiona al regidor Francisco Javier Somoza, quien, igual que los de Lugo y Betanzos, reconoce que existían problemas en la ciudad, que solían producirse graves desórdenes y abusos en las elecciones. Señala, además, que las elecciones estaban viciadas, pues se tomaba excesivo interés en que salieran elegidos parientes de panaderos, mesoneros, taberneros o abastecedores, con el fin de elevar los precios o tolerar sus fraudes al público, razón por la cual los vecinos honrados ya no acudían a votar y se generaban «odios» en los electos contra el resto de los munícipes. Y concluye que, si no se consideraba oportuno suprimir «como inútiles» los mencionados oficios, a los que imputa haber «eclisado el esplendor y reputación de las ciudades», sí al menos se debería reformar el procedimiento de elección, proponiendo que se siguiese uno parecido al utilizado para la designación del procurador general. En realidad, era una mezcla de éste y del sistema de cobrados usado para nombrar los alcaldes ordinarios; o sea, con unas elecciones controladas desde dentro del ayuntamiento ${ }^{39}$. Ni que decir tiene que éste respaldó la proposición, aunque en las altas instancias no debió tenerse en cuenta, pues la mecánica electoral continuó siendo la misma.

Más allá del resultado, esto como todo lo anterior nos habla de una crisis del sistema a nivel local, en lo que atañe a las instituciones municipal y señorial, pero también de las resistencias de los poderes tradicionales a las reformas y remodelaciones planteadas por la Corona. Una crisis y la consiguiente dialéctica que desde luego precede de largo a la quiebra final del Antiguo Régimen. Aunque no es menos cierto que en la década final del XVIII y primeros años del XIX se impulsa, iniciándose ya la fase de descomposición. Solo hará falta una crisis institucional de gran envergadura, como la de 1808, para que la quiebra o ruptura entre además en fase de expresión jurídica e institucional.

\section{EL RÉGIMEN MUNICIPAL DURANTE LA OCUPACIÓN FRANCESA}

El inicio del cambio en las estructuras del gobierno local se gestó con el estallido de la guerra en 1808. El detonante fue la ocupación de Madrid por parte de las tropas

39. Concretamente, el procedimiento sería el siguiente: el 31 de diciembre, reunido el ayuntamiento en pleno (capitulares) con el procurador general, los cuatro diputados del común y el sindico personero votarían para proponer como diputados a cuatro personas «hábiles e idóneas» y para procurador personero otras dos. Al tiempo se hallarian once compromisarios (vecinos de conocida honradez), escogidos en las once parroquias (cinco de ellos por un regidor y el procurador general y los otros seis por otro regidor y el síndico personero), que serían los que, finalmente, elegirían a los dos diputados y al síndico personero que habían de servir los cargos durante el año siguiente (AHUS, Municipal, LdC 1808, $\mathrm{n}^{\circ}$ $306, \mathrm{CO} 12 / 1 / 1808$, ff. $235-238,215 \mathrm{v}$ ). Por lo que sabemos, los conflictos, tensiones y presiones en los comicios celebrados para elegir diputados y personeros del común fueron abundantes también en otras localidades; véase, a modo de ejemplo, GARCIA MONERRIS, Encarnación: La Monarquía absoluta y el ayuntamiento borbónico (La reorganización de la oligarquia urbana en el Ayuntamiento de Valencia: 1707-1800), Madrid, 1991, pp. 358-374; y SÁNCHEZ SALAZAR, Felipa: «El control del poder local: elecciones municipales en tierras de Jaén en el siglo XVIII y primer tercio del XIX», en Actas del II Congreso de Historia de Andalucia (Córdoba, 1991, Andalucía Moderna III), Córdoba 1995, p. 620. 
hasta entonces consideradas aliadas, la renuncia de Fernando VII y posterior nombramiento de Murat como lugarteniente general del Reino. En los días que siguen y dadas las noticias que llegan a Galicia, algunas ciudades se plantean organizar una Junta similar a las que estaban formándose en otras localidades no ocupadas ${ }^{40}$. Coruña fue la pionera, creándola el 30 de mayo de dicho año. Ese mismo día 30 por la noche el arzobispo hizo lo propio en Santiago: constituyó una Junta de Armamento y Defensa, que toma las riendas del poder. Dicha Junta se componía de diecinueve vocales, la mayoría de los cuales eran miembros del clero (seis), considerado un instrumento disuasor de posibles levantamientos de masas, algunos representantes de la Universidad, otros de la hidalguía rentista y del comercio local, además de tres sujetos no identificados (posiblemente militares y jueces) y sólo un miembro del cabildo municipal; hecho este último que López Ferreiro achaca al referido contencioso que mantuvieran el prelado y el concejo por el señorío de la ciudad, así como a la desconfianza que algunos de sus integrantes provocaban en el pueblo, mayormente porque el mismo día 31 éste había publicado un bando en el que proclamaba al gran duque de Berg Murat como lugarteniente general del Reino de España ${ }^{41}$. En virtud de ello la gobernación municipal pasó a manos del prelado, que es quién preside la mencionada Junta y tiene como vicepresidente un canónigo. O sea, que sigue estando en manos de un poder que encarna el Antiguo Régimen.

E1 2 de junio la Junta de Coruña convoca y acuerda declararse Suprema y Gubernativa en el Reino de Galicia, en nombre de Fernando VII, arrogándose el derecho de dictar providencias sobre todas las demás juntas ${ }^{42}$. La medida disgustó a las otras Juntas Locales, especialmente a la de Santiago que continuó ejerciendo a su vez un poder que Barreiro Fernández califica de «prácticamente soberano», iniciándose entonces una guerra abierta entre ambas juntas, que fue alimentada por el arzobispo al

40. Caso, por ejemplo, de Palencia (SÁNCHEz ARCLlla BernAl, José: «El municipio de Palencia durante la ocupación francesa, 1808-1813. Notas para el estudio del régimen municipal josefinista», cn MERCHán Farnandiz, Carlos (coord.): Actas del l Congreso de Historia de Palencia, 1987, III, pp. 69-139, esp. 86-87). Como ocurrió alli, también aquí previamente se había comunicado al ayuntamiento la renuncia de Fernando Vli a la Corona, mediante una carta del Consejo de Castilla, así como el nombramiento de Murat como lugarteniente del Reino y la aceptación del duque de Berg de dicho cargo y el de presidente de la Junta Suprema de Gobierno. Igualmente, el 25 de mayo, por una real orden de éste se notificaban los deseos del Emperador de reunir en Bayona una «Diputación General» de 150 personas, compuesta de «Clero, Nobleza y Estado General para tratar de la felicidad de toda España, proponiendo todos los males que el anterior sistema le han ocasionado, y reformas y remedios más convenientes para destruirlos en toda la nación, y cada provincia en particular» (AHUS: Municipal, LdC 1808, $n^{\circ} 307, \mathrm{CO} 25 / 5 / 1808$, f. 30). Santiago, como ciudad de voto en Cortes a quien toca designar diputados junto con la de Coruña, debía enviar dos: nombran a don Joaquín de Luna, marqués de Camarasa, natural del Reino pero residente en Madrid, que no acepta, y a don Joaģuín Tenreiro Montenegro, síndico procurador general que fue el año 1807 por la clase de caballero, que entonces estaba también en la Corte (CO 27/5/1808, ff. 34-35; CO 17/6/1808, Г. 96).

41. López Ferreiro, Antonio: Historia, op. cit., pp. 131-132.

42. AHUS: Municipal, LdC 1808, $n^{\circ} 308, \mathrm{CO} 7 / 7 / 1808$, f. 70. 
considerar que él debería ser el presidente de aquélla ${ }^{43}$. Igualmente, tensas fueron las relaciones de la Junta compostelana con el ayuntamiento, dado que éste, amparado por la Junta del Reino, se muestra renuente a colaborar cuando no entorpece la acción de aquélla ${ }^{44}$. Por el contrario, el vecindario parece estar del lado de la Junta, colaborando siempre que se le requiere a través de proclamas, edictos o bandos publicados al efecto, lo mismo que el cabildo eclesiástico ${ }^{45}$. En cambio, ve con desconfianza la actuación del consistorio, tal y como se puso de manifiesto las noches del 21 y 22 de junio: los ánimos populares estaban tan exaltados que se produjeron una especie de motines en contra del ayuntamiento. Hecho que las autoridades municipales se apresuraron a denunciar ante la Junta Suprema del Reino para que tomara las providencias oportunas, con el fin, decían, de evitar que se repitieran ${ }^{46}$.

Un paso más en el modelo de gobierno que se instaló durante estas fechas, precisamente para evitar estas rivalidades y tensiones, se da en el mes de julio con la instauración de un gobernador militar en Santiago y su provincia por orden de la Junta Suprema del Reino. Se designa como tal al oficial de marina don Juan Alonso de Espino $y$, entre otras funciones, se le encomienda presidir una «junta de seguridad» que estaría compuesta por el alcalde mayor, un regidor, un diputado del común, el personero del común, un caballero de distinción y un asesor si fuere necesario, a quien se encarga conocer de todas las causas de malhechores, ladrones, contrabandistas, revoltosos y detractores del gobierno, sin por ello derogar el que competía a los jueces ordinarios ${ }^{47}$. Disgustó y mucho la medida a la Junta compostelana, pero sobre todo a su presidente, el prelado, así como al codepositario del señorío, el cabildo eclesiástico, quienes acordaron aprobar una protesta por lo que podía perjudicar dicho nombramiento «a la jurisdicción civil y criminal que ejercen los Jueces nombrados por la Iglesia $\rangle^{48}$, o sea, a las justicias señoriales (asistente o alcalde mayor y juez de la quintana).

En todo caso, estas circunstancias de excepción duraron sólo unos meses, pues a finales de septiembre de ese mismo año se crea la Junta Suprema Central, en Aranjuez, que presidida por Floridablanca contaba entre sus componentes por Galicia al regidor compostelano conde de Gimonde y al tudense don Manuel de Aballe. Entre otras disposiciones, el meneionado órgano central ordenó la extinción de las Juntas que se habían formado en las localidades cabeza de partido, con lo cual la dirección política de la ciudad, trasvasada desde la Junta a la corporación municipal, tuvo asegurada la continuidad de gobierno, ya que las antiguas autoridades aunque no participaron en

43. Barreiro FErnÁNDEz, Xosé Ramón: Historia contemporánea, op. cit., pp. 52-53. Sobre las tensas relaciones de ambas juntas, antes López Ferrerro, Antonio: Historia, op. cil., pp. 139-148.

44. A principios del mes de agosto, por ejemplo, hay divergencias por la ocupación de la sala consistorial y cl retrato de Fernando VII (AHUS: Municipal, LdC 1808, n³08, CO 10/8/1808, ff. 328-328v, 322-322v, $324-324 v)$.

45. BARreiro FernÁndez, Xosé Ramón: Historia contemporánea, op. cit., p. 148.

46. AHUS; Municipal, LdC 1808, n³ 307. CO 24/6/1808, ff. 105, 106-107; n" 308, Co 10/8/1808, f. 323.

47. Ibidem, n" 307, CO 30/6/1808, f. 242; n" 308, CO 6/8/1808, ff. 356-357v.

48. Widem, CO 10/8/1808, ff. 328-328v; LÓpez Ferreiro, Antonio: Historia, op. cit., p. 143. 
pleno en aquélla estuvieron representadas (recuérdese, un regidor) y además su instauración (como Junta de Defensa y Armamento) no supuso la desaparición o disolución formal del ayuntamiento. A partir de entonces proliferó por parte de éste la creación de juntas particulares para la administración de los distintos ramos, a instancias de la Junta del Reino o de los mandos militares.

En los primeros días del mes de enero de 1809 se inicia la gran invasión de los franceses sobre Galicia, lo que dará lugar a una nueva situación de excepción. Teniéndose conocimiento de ello en la ciudad a través de un oficio del Reino, y para evitar desavenencias como las ocurridas durante los meses precedentes entre la Junta Permanente y el ayuntamiento, el día 7 del mencionado mes se reúnen las dos corporaciones en el consistorio bajo la presidencia del arzobispo (en «Junta de Gobierno») para hablar sobre los medios y medidas a tomar (en cuanto a «armamento y alistamiento de gente») para la defensa de la religión y de la patria ${ }^{49}$. Lo mismo ocurriría en otras sesiones posteriores donde se acuerda disponer todos los aprestos necesarios para la campaña y defensa de la ciudad ${ }^{50}$. Con poca efectividad, pues el día 13 ya se publica un bando, dando cuenta del cercamiento a que la someten las tropas francesas. Incluso en esa misma junta o «congreso de autoridades de Santiago» se acuerda nombrar una diputación que les manifieste el deseo del pueblo de recibirles en paz ${ }^{51}$.

Es el principio de la ocupación francesa que se produce el día 17 cuando una avanzada del general Franceschi, del ejército de Soult toma la ciudad sin apenas dificultad, con la consigna de apoderarse del arzobispo Múzquiz. Pero éste, igual que algunos miembros del cabildo eclesiástico, había huido. Después vendría la entrada en la ciudad, la proclama de Napoleón, el juramento de sumisión al rey José I y el acta de capitulación de las autoridades locales ${ }^{52}$.

En lo que a la gobernación se refiere, como primera medida las autoridades militares ocupantes, encabezadas por el general Marchand, procuraron rodearse de afectos al partido francés: así, el 20 de enero nombran como «alcalde adjunto» al catedrático don Manuel Sánchez Boado y Fraguio, para que lo fuese juntamente con el que estaba designado por el arzobispo ${ }^{53}$, y a Bazán de Mendoza como jefe de policía y director de la Universidad. Apenas transcurridas unas semanas reforzaron las atribuciones de Sánchez Boado, designándolo además «prefecto de policía» al mando de la restablecida milicia honrrada (según notificación recibida en el ayuntamiento el día 12 de febre-

49. En realidad, reza el encabezamiento «En este Ayuntamiento, Junta de Gobierno y Congreso que han celebrado los señores Justicia y Regimiento, Junta de Gobierno, Priores de Comunidades y pudientes de esta Muy Noble y Muy Leal ciudad de Santiago» (AHUS: Municipal, LdC 1809, ñ 309 (dominación francesa), CO 7/1/ 1809). Trascribe la primera de las actas de consistorio mencionada LÓPEZ FERREIRO, Antonio: Historia, op. cit., pp. 157-158.

50. Ibidem, pp. 159-160.

51. AHUS: Municipal, LdC 1809, $\mathrm{n}^{\circ} 309$ (dominación francesa), CO 13/1/1809, f. 1 y ss.

52. Ibídem, CO 19/1/1809, f. 15; CO 24/1/1809, f. 66; CO 25/1/1809, f. 81; CO 27/1/1809, f. 107, etc.

53. Y a fin de favorecer el aprovisionamiento, alojamientos, bagajes y demás de la tropa francesa (Ibidem, CO 20/1/1809, f. 21). 
ro) y «corregidor de la ciudad y provincia» (el 17), en ambos casos, se explicita, con derecho a «acompañarse» de seis personas «a su elección» que le ayudasen en dichas tareas (junta de prefectura o «juzgado de policía»), y obligación de rendir cuentas en cuanto al primero ante el comandante de la plaza y de lo relativo a la provincia ante el gobernador cada cinco días o más frecuentemente si fuese necesario $0^{54}$.

Por lo que atañe a la municipalidad, quisieron que como regidores prosiguiesen los que estaban, dando así continuidad legal al modelo de gobierno en una situación de excepción, aunque se les exigió puntual y diaria asistencia so pena de graves multas ${ }^{55}$. $Y$ ello a pesar de que a los pocos días de llegar dispusieron que los oficios, contestaciones y acuerdos del consistorio pudiesen suscribirse con la sola firma de un alcalde $y$ dos vocales ${ }^{56}$. Además, nombraron un intérprete (don Juan Sadarini ${ }^{57}$ ) y, entre las personas más destacadas de la ciudad, a algunas que junto con los regidores, diputados del común y personero asistiesen a las juntas o «congresos de autoridades» en representación de las distintas clases sociales, sectores profesionales e instituciones ${ }^{58}$. Por último, con relación a la administración de justicia, a instancias de Sánchez de Boado y como un medio de procurar y preservar la tranquilidad pública, ordenaron que se abrieran las Audiencias y que los jueces continuaran con el despacho de las causas tanto civiles como criminales ${ }^{59}$.

Se trata de medidas puntuales (más del ejército francés quizás que de la Administración josefinista), encaminadas primero a controlar la situación tras la ocupación (de ahí que aboguen por la continuidad institucional) y después a regularizarla con pequeñas reformas, pero significativas ${ }^{60}$. Lo más llamativo, aparte de la designación de un prefecto para la ciudad y provincia, es la nueva composición del ayuntamiento, que preside el corregidor, en el que no figuran los alcaldes ordinarios y procurador general, y al que se incorporan esos nuevos concejales designados por la

54. Se le permite elegir «las más recomendables para su moralidad, conocimientos y afecto al gobiemo actual del Reino, y al restablecimiento y subsistencia del buen orden»; en concreto, los señores propuestos para el juzgado de policía son: don Francisco Trillo de Soto, don Juan Francisco Javier Somoza, don José González Varela, don Agustín Vales Bahamonde, don Ramón Pérez de Santa Marina, don José Castiñeiro, don Andrés Maquiaras y Diz, y don Diego González Acebedo (Ibidem: LdC 1809, n³09, CO $11 / 2 / 1809$, f. 258 y CO $17 / 2 / 1809$, ff. 293-293v y 300 ).

55. Ibidem, CO 2/2/1809, f. 146; CO 5/2/1809, f. 187 y 197.

56. Ibidem, CO 23/1/1809, f. 47.

57. Ibidem, CO $3 / 2 / 1809$, f. 161 .

58. En concreto, dos representantes de la clase de los pudientes (don Antonio Gil y don Diego Vasadre), cinco por la Universidad y letrados (don Agustín Vales, don Joaquín Flórez, don Francisco Pardo, don Andrés Parga y don Diego Acevedo) y cuatro por el comercio (don Ramón Pérez Santa Marina, don Manuel de la Riba, don Anselmo Cabello y don Juan Bovadilla), quedando por los demás estados el personero «por ser así su obligación» (Ibídem, CO 4/3/1809, ff. 403-403v).

59. Ibidem, CO 21/1/1809, ff. 29, 30, 31 y 33 .

60. A nivel comparativo, sobre el régimen municipal josefista, que se desarrolla durante los años 1809 y 1810 , vid. SÁNChEZ-ARCILlA BeRnAL, José: Del municipio, op. cit., pp. 645-650; El municipio de Palencia, op. cit.; y GARCÍA FERnÁNDEZ, Javier: El origen del municipio, op. cit., pp. 191-210. 
autoridad militar. Se apunta asimismo una restricción de la autonomía municipal, lo cual no es nuevo, pues se inserta en la corriente centralizadora del XVIII, sobre todo de Carlos III, merced al establecimiento de un funcionario (el corregidor) que enlaza con la administración central, a través del gobernador o comisario regio en la provincia. $\mathrm{Y}$, en eambio, subsiste la confusión de lo municipal y lo judicial en esa figura, a la que se dota de atribuciones judiciales y gubernativas, siendo el principal encargado del gobierno de la municipalidad.

Con todo, son medidas de carácter circunstancial y alcance muy limitado, pues la ocupación apenas dura cuatro meses. De hecho, el día 18 de junio las tropas francesas salen de la ciudad, siendo acompañadas por el corregidor de la ciudad y provincia, a la sazón don Antonio Gil Lemos. Regresan al día siguiente, fecha en la que el congreso municipal hace presente al general Marchand la necesidad de nombrar un letrado que durante la ausencia de aquél ejerciera sus funciones. Así lo hizo, notificando su nombramiento al concejo el mismo día 20 , fecha en la que las tropas francesas abandonaron Santiago para no volver ${ }^{6 !}$.

Claro que desde mediados de mayo dicha ocupación ya se había empezado a tambalear y con ello las bases de su administración. De hecho, el 23 de dicho mes la ciudad fuera recobrada por la División del Miño, al mando del general Martín de la Carrera $^{62}$. Los acontecimientos se suceden entonces con gran rapidez: al día siguiente declara nulo el juramento de sumisión y reconocimiento como rey de España de José I al tiempo que proclama a Fernando VII, y al otro (25 de mayo) una junta de los alcaldes ordinarios, diputado del común y personero «llevando las funciones del (procurador) general», a instancias del general Carrera, declara restablecido el concejo con los capitulares que lo integraban antes de la ocupación, requiriéndoles a que volviesen y asistiesen ${ }^{63}$. Por poco tiempo, pues el 4 de junio reaparecen en la ciudad dos de las principales autoridades nombradas por los franceses como eran Fraguío y Bazán de Mendoza. E1 5 está de paso en ella el mariscal Ney, quien sale con su ejército para Ponte San Payo. Retorna vencido seis días más tarde y aquí permanecería hasta el 20 , día en el que los franceses, ahora sí, se marchan definitivamente de la ciudad ${ }^{64}$.

En cuanto salieron de Galicia, el capitán general de Galicia, marqués de la Romana, procura recuperar el poder que tradicionalmente había ejercido. De hecho, una sus primeras medidas fue designar al conde de Noroña segundo comandante del ejército y reino de Galicia, al tiempo que dispone el cese de todos los empleados designados por el gobierno francés y restitución de las cosas al estado que tenían antes de la ocupación, incluida la suspensión de los arbitrios y contribuciones impuestas por

61. AHUS: Muncipal, LdC 1809, no 310, CO 18/6/1809, f. 302; CO 19/6/1809, f. 307; CO 20/6/1809, i. 311.

62. Barreiro FERnANDEz, Xosé Ramón: Historia contemporánea, op. cit., pp. 107-109.

63. AHUS, Municipal, LdC 1809, n' 310, CO 24/5/1809, f. 36 y CO 25/5/1 809, f. 40, respectivamente.

64. Sobre la liberación de Santiago y la batalla de Sampayo, aparte de la obra y bibliografía allí citada, LOPEZ Ferreiro, Antonio: Hisioria, op. cit., IX, pp. 203-227. 
el extranjero ${ }^{65}$. Sin embargo, obvia constituir una nueva Junta del Reino, que, según parece, era la opción preferida por el clero y la hidalguía, respaldada por los ingleses ${ }^{6{ }^{6}}$. Una operación que, si hemos de creer a Barreiro Fernández, conecta con su ideología absolutista y temor de que al socaire de las circunstancias políticas se introdujeran nuevos poderes representantes del pueblo ${ }^{67}$. En el mismo sentido cabe interpretar la conservación del cargo de «gobernador militar y político de la ciudad y provincia», que la Junta del Reino creara antes de la ocupación y que los franceses mantuvieron durante la misma. Designa como tal al mariscal don Francisco Taboada y Gil, a quien otorgó poderes ilimitados «para obrar según lo exigen las circunstancias del día» con todos los cuerpos, así «eclesiásticos, militares, políticos y demás individuos», y delitos que perturben la paz ${ }^{68}$.

Por lo que respecta a la dirección política de la ciudad, trasvasada desde la «Junta de los señores alcaldes, diputado del común u personero (con funciones del general)»que hay que suponer heredera del «Ayuntamiento y Junta Permanente de gobierno» que se había formado en enero bajo la presidencia del arzobispo ${ }^{69}$ - a la corporación municipal, tuvo asegurada la continuidad de gobierno, pues las antiguas autoridades estuvieron en todo momento integradas en la mencionada junta, que se extingue cuando se declara restablecido el concejo con los capitulares que lo formaban antes de la invasión francesa. Siendo así que cuando en octubre la Junta Central ordenó la extinción de todas las juntas que no fueran superiores o de cabeza de partido, el cabildo compostelano pudo contestar que no tenía noticia de que existiera ninguna particular ni de partido en la ciudad ni tampoco en la provincia ${ }^{70}$. Claro que esas mismas personas habían formado parte también de la municipalidad establecida por la administración josefista, no tanto por la mayor o menor simpatía que pudieran tener por la causa francesa, cuanto por el modelo de gobierno instalado en estas fechas, caracterizado por la continuidad legal. Y continuidad sigue habiendo ahora, aunque se busque otro entronque.

En los meses que siguen poco a poco se va a ir normalizando la situación política de la ciudad. Así, el 29 de julio, por ejemplo, se celebra un ayuntamiento en el que se eligen los oficios y reparten las comisiones de ese año (capitular archivero, capitular cartero, capitular encargado de la dirección de las escuelas de primeras letra, etc.) y a comienzos del año 1809 se vuelve a hacer lo propio ${ }^{71}$. En diciembre regresa a la

65. AHUS: Municipal, LdC 1809, n 311, CO 4/7/1809, ff. 62-62v.

66. GonzÁlez López, Emilio: El Águila desplumada, Vigo, 1988, pp. 22-24.

67. BARREIro FERnANDEZ, Xosé Ramón: Historia contemporánea, op. cit., pp. 128-129.

68. AHUS: Municipal, LdC 1809, n³11, CO 9/7/1809, f. 94-94v; CO 10/7/1809, f. 96-97.

69. Es indicativo, al respecto, el hecho de que en el Libro de Consistorio donde consta la unión del ayuntamiento y de la Junta permanente, bajo la presidencia del arzobispo Múzquiz, a principios de enero así como algunas de las medidas que adoptaron (Ibidem, LdC 1809, $\mathrm{n}^{\circ} 311$ ), no vuelva a contener consistorios desde el mes de enero hasta el de mayo, en que se restablece el ayuntamiento antiguo (CO 25/4/1809, f. 40 ).

70. Ibidem, LdC 1809, n“312, CO 14/10/1809, f. 46.

71. Ibidem, CO 29/7/1809, ff. 154-154v; LdC 1810, n"313, CO 4/1810. 
diócesis el arzobispo Múzquiz. Y a finales de este mismo mes el consistorio elabora los cobrados y aquél elige entre los propuestos los dos alcaldes del año 1810, que después prestarían el juramento acostumbrado. Bastante antes, a principios de agosto ya se había presentado un título de regidor, despachado por el provisor, merced a la renuncia efectuada por el propietario y padre del nominado. Pese a todo, la ausencia e inasistencia de los capitulares sigue siendo la tónica dominante, hasta el punto de que el gobernador de la ciudad y provincia a mediados de septiembre dispuso que «las dos terceras partes (de los vocales) alternativamente, según sus precisiones», estuvieran permanentemente en la capital y la otra tercera parte, turnando, que pudiera atender al cuidado de sus haciendas y familias; eso sí, «llebando el pasaporte y licencia que en semejantes casos se les concederá», so pena de 200 ducados y, no pagándolos, de ser suspendidos de sus empleos y tenidos por negligentes ${ }^{72}$.

\section{EL MUNICIPIO CONSTITUCIONAL EN SU PRIMERA ETAPA (1812-1814)}

Prescindiendo de lo acontecido entre 1809 en que la Junta Suprema decide convocar Cortes hasta la aprobación de la Constitución de Cádiz, y centrándonos exclusivamente en el régimen municipal allí pergeñado, cumple recordar que la primera medida tomada por aquéllas que afecta a éste es el famoso decreto de 6 de agosto de 1811 , por el que quedaban incorporados a la nación todos los señoríos jurisdiccionales de cualquier clase y condición. En efecto, se estipula el cese de sus corregidores, alcaldes mayores y demás empleados, «a excepción de los Ayuntamientos y alcaldes ordinarios, que permanecerán hasta fin del presente año», indicando que el nombramiento de todas las Justicias y funcionarios públicos se debía hacer «por el mismo orden y según se verifica en los pueblos de realengo» ${ }^{73}$.

En Santiago se recibe una copia del decreto a finales de septiembre y se genera incertidumbre sobre su aplicación, sobre todo en lo que atañe al nombramiento de los alcaldes ordinarios. De hecho, a principios de noviembre se recibe un carta de la villa de Pontevedra, también dependiente del señorío arzobispal, solicitando información acerca del método que se había de seguir para su elección (hasta entonces mediante cobrados), por ver si se mantenía el procedimiento (propuesta del ayuntamiento y revisión mediante once vecinos, con capacidad para aprobarla o reprobarla), y remisión en su caso de la propuesta al Real Acuerdo en vez de al señor. Y en diciembre llega otra similar procedente de Lugo amén de consultas de algunas villas de la provincia ${ }^{74}$. Las autoridades compostelanas reconocen las mismas dudas, por lo que deciden consultar al Real Acuerdo.

72. Ibidem, LdC 1809, n³ 311, CO 14/9/1809, ff. 289-289v, 290-291 y 300 .

73. SÁnchez-ARCilla Bernal, José: Del municipio, op. cit., p. 652; Garcia Fernández, Javier: El origen del municipio, op. cit., pp. 233-243.

74. AHUS, Municipal, LdC 1811, nº 317, CO 24/9/1811, ff. 94, 63-64 (copia del decreto); CO 10/11/1811, ff. $159-159 \mathrm{v} ; \operatorname{CO} 9 / 12 / 181 \mathrm{l}$, ff. $246-246 \mathrm{v}$ y $240 ; \operatorname{CO} 24 / 12 / 1811$, ff. 265-265v y 263-263v. 
A finales del mismo mes se vuelve sobre el asunto, en esta ocasión a instancias del procurador general y del personero, quienes presumen que la nominación de alcaldes era «enteramente popular» y que, aunque el decreto suprimiera los señoríos, no podía entenderse derogado el expresado derecho y posesión inmemorial del pueblo, reconocido por diversas sentencias y ejecutorias reales. Se delibera sobre ello y las posiciones son contradictorias: el alcalde más antiguo y presidente de la corporación, en concreto, se opone, aduciendo que la elaboración de cobrados en esos términos era una «trasgresión e infracción de la ley», aunque por mayoría se acordó hacerlo. Mas no hubo tiempo, pues a los pocos días se recibió un oficio del Real Acuerdo, ordenando que la elección se efectuara por ahora con arreglo a las instrucciones que regían en el nombramiento de los diputados del común y personero, y que los que obtuviesen mayor número de votos fuesen investidos como tales ${ }^{75}$. Cosa que así se hizo los días 19 y 20 de diciembre, saliendo electos los abogados Domingo Vales y Joaquín Bernardo Flores, que ya ejercieran el cargo otras veces. Se excusan de volverlo a hacer por sus respectivas ocupaciones, pero el Acuerdo no acepta sus descargos ${ }^{76}$.

Después le toca el turno a los regidores, algunos de los cuales eran también de provisión episcopal. En respuesta a consulta del ayuntamiento, el 23 de diciembre el Real Acuerdo despacha un primer auto sobre la forma en que se debían elegir los alcaldes, regidores y demás oficios repúblicos que proveía el arzobispo como señor jurisdiccional en las villas y localidades de la provincia. En lo que atañe a la capital, la corporación no obstaculizó pero sí se mostró renuente a la aplicación de la ley, alegando que los veintidós regidores eran perpetuos y que servían el cargo por derecho de sus casas, sin que el prelado tuviera más derecho sobre ellos que el de la confirmación derivada de la renuncia ${ }^{77}$. No convenció al Acuerdo, que el 6 de febrero de 1812 dicta otro auto aclaratorio, disponiendo que se cumpliera lo mandado por la providencia del 19 de diciembre $y$, en consecuencia, que provisionalmente sólo continuaran ejerciendo sus empleos quienes los tenían en virtud de cédula real y que cesaran todos los demás ${ }^{78}$. No nos consta la relación de asientos vacantes, pero por resolución posterior del mismo órgano sabemos que fueron catorce (suponemos, oficios con uso, pues los renunciables eran diecisiete). De hecho, éste fue el número de «regidores interinos» que el Acuerdo designó para la ciudad el 21 de marzo, en realidad las mismas personas que hasta

75. Ibidem, CO 1/12/1811, ff. 222 y 220-220v; CO $2 / 12 / 1811$, ff. 224-225; CO 9/12/1811, f. 246.

76. Previamente, se había convocado a los cuadrilleros de las diez parroquias de la ciudad, cada uno designa a las doce personas electoras de su respectiva parroquia, y éstos proponen dos personas (por parroquia), uno para alcalde primero y otro para alcalde segundo, resultando electos los dos más votados (Ibídem, CO 19/11/1811; CO 27/12/1811, ff. 271-290v); LdC 1812, n 318, CO 1/1/1812, ff. 296-297).

77. Ibidem, LdC 1811, CO 24/12/1811, f. 265-265v. Está en la línea de hostilidad adoptada por el arzobispo de Santiago y demás miembros de la jerarquia eclesiástica gallega en contra de la promulgación primero y ejecución después de ciertas leyes, como la de abolición de los señoríos, extinción del voto de Santiago o extinción de la Inquisición. En lo que a la primera se refiere, aquél hizo caso omiso del decreto, y siguió titulándose «señor de Santiago», so pretexto de que la titularidad de dicho señorío no era de la Mitra sino del Apóstol (Barreiro Fernández, Xosé Ramón: Historia, op. cit., pp. 148-153).

78. AHUS: Municipal, LdC 1812, $\mathrm{n}^{\circ} 318, \mathrm{CO} 14 / 2 / 1812$, f. $64 \mathrm{v}$. 
entonces ocuparan esas plazas con título episcopal ${ }^{79}$. Pura formalidad: se cambia el sistema de provisión de los cargos del consistorio, pero no a quienes los ocupan; acaso para evitar más problemas de los que ya estaba ocasionando la ejecución del decreto de abolición de señoríos jurisdiccionales y a la espera de lo que las Cortes gaditanas legislaran sobre el gobierno de los pueblos.

Aun así, algunos de los designados solicitaron ser exonerados y el Acuerdo acepta su dispensa, sin que conste la designación de otros en su lugar. Se entiende, porque el 12 y 13 de enero se había celebrado el debate parlamentario sobre la reforma del régimen municipal, una regulación que se vio posteriormente complementada y desarrollada por tres decretos (el de 23 de mayo con su complementario de 10 de julio y la Instrucción de 23 de junio de 1813). El 20 de junio el capitán general remite una copia del texto de la Constitución a la ciudad, se preparan los festejos y el 5 de julio se procedió en el ayuntamiento a jurarla, conforme al decreto de 18 de marzo ${ }^{80}$. El 30 del mismo mes los miembros de la corporación elevan una representación a la Audiencia, exponiendo sus dudas sobre si debían continuar ejerciendo su empleo, a lo cual responde el Regente que, tras la publicación de la Constitución gaditana, no puede el Acuerdo tomar resolución alguna al respecto, pues sus competencias se ciñen a lo contencioso ${ }^{81}$.

Días más tarde éste remite un oficio, inclusa una real orden, de cara a la instalación del primer ayuntamiento constitucional. Atañe a la elección de alcaldes ordinarios, que manda efectuar. El 13 de agosto es el capitán general quien da traslado a otra disposición de la Regencia, ordenando la elección de regidores conforme al Decreto de 23 de mayo ${ }^{\$ 2}$. Sin entrar a analizar su contenido ni el del resto de regulaciones doceañistas tocantes a régimen municipal, pues hay bibliografía autorizada para ello ${ }^{83}$, es indudable que los principios recogidos en la Soberana Ley suponen un auténtico vuelco de aquél, pues la representatividad ciudadana, a través de las elecciones, concretaba su composición y aseguraba la participación popular ${ }^{84}$. En Santiago, específicamente, por su condición de capital de provincia la nueva planta municipal estará formada por dos alcaldes, doce regidores y dos procurados síndicos generales. En cuanto a la elección hay limitaciones de base: sólo podían ser electores y elegibles los vecinos cabezas de familia residentes y con propiedades o trabajo estable en el municipio ${ }^{85}$. De

79. Hidem, $\mathrm{CO} 28 / 3 / 1812$, ff. $157-161$

80. Wbidem, CO 16/5/1812, f. 262v; CO 21/6/1812, f. 348; CO 22/6/1812, ff. 351-35lv y ss; CO 5/7/1812, ff. $401-401 v ; \operatorname{CO~6/7/1812,~ff.~402-404;~CO~9/7/1812,~ff.~410-410v,~etc.~}$

81 . Hidem, $\mathrm{n}^{\circ} 319, \mathrm{CO} 7 / 8 / 1812$, ff. 9,5 y $6-7$.

82. Ibidem, f. 9; CO 13/8/1812, f. 17.

83. DE CASTRO, Concepción: La Revolución Liberal y los municipios españoles (18112-1868), Madrid, 1979. pp. 57-120; SANCHEZ-ARClLla BERnAl, José: Del municipio, op. cit., pp. 650-663; GARCíA FLRNÁNDEZ, Javier: El origen del municipio, op. cit., pp. 233-301 y bibliografía citada.

84. ARTOLA Galligo, Miguel: Antiguo Régimen y Revolución liberal, Madrid, 1978, p. 81; «La España de Fernando VIl», en Historia de España de Menéndez Pidal, Madrid, XXVI, 1968.

85. D: CASTRo, Concepeión: La Revolución, op. cit., pp. 73-77. 
ahí que no sorprenda el resultado: el gobierno municipal recae en personas de prestigio o poder económico de la ciudad. Otra cosa es que, una vez eliminados los privilegios estamentales y la perpetuidad de los oficios, la clase media -o la tan traída y llevada burguesía stricto sensu- fuera, como se ha dicho, la única llamada a representar a su comunidad $^{86}$.

En efecto, igual que en otras localidades ${ }^{87}$, dentro del colectivo de electos ${ }^{88}$ se constata la presencia de un mayor número de miembros de la burguesía, pero un sector sigue procediendo de la antigua oligarquía urbana -regidores, nobles o familias tradicionalmente vinculadas al poder local-, otros ya tienen experiencia concejil en el desempeño de cargos concejiles electivos - como personeros o diputados del común, caso de los adinerados burgueses Anselmo Cabello o Silverio Moreno Ibáñez ${ }^{89}$-, y el resto son personas que pisan el ayuntamiento por primera vez, entre los que figura uno de ilustre apellido pero pocos posibles como es Francisco Ferro Caaveiro, descendiente del arquitecto Lucas Ferro Caaveiro ${ }^{90}$. En general, salvo un puñado de ricos hacendados o propietarios y algún que otro rico hombre de negocios, como los antes mencionados, se trata de individuos con profesiones liberales, es decir, abogados, catedráticos de Universidad, comerciantes e incluso puede que alguno del sector artesanal (entre los desconocidos). Como balance de esta primera corporación constitucional, no se puede decir que la continuidad prevaliera sobre el cambio"1, si acaso van parejas, con una particularidad: y es que ese continuismo esta representado por miembros de la élite e hidalguía urbana, entre los que se cuelan dos regidores perpetuos (tenientes), siendo los demás descendientes y herederos de titulares de oficios renunciables o bien individuos que antes fueran alcaldes ordinarios, procurador general e incluso personero del

86. Ihidem, p. 74.

87. Como Alịcante (Álvarez Y CAÑAS, Ma Luisa: El gobierno de la ciudad, op. cit., pp. 281-282); véase también infra, nota 89.

88. La relación de personas elegidas en esta primera corporación constitucional (AHUS: Municipal, LdC 1812, n' 319, CO 14/8/1812) es la siguiente: como alualdes, el doctor don Joaquín Bernardo Flores (primero) y el licenciado don Domingo Vales (segundo); como regidores, por este orden, don Francisco Montenegro, don Francisco Xavier Losada, don Julián Suárez Freire, don Pedro Maria Bermúdez, don Miguel Cotón, el doctor don Agustín Vales Vaamonde, don Anselmo Cabello, don José Ozores Villafane, don Francisco de Ponte y Andrade, don Francisco Xavier de Gándara y don Francisco Ferro Caaveiro; y, como procuradores, don Simón Maria Pedrosa (primero) y el conde de San Juan, don José Calderón (segundo).

89. Dos de las once lirmas compostelanas que en el año 1808 arrojaban un saldo de mảs de un millón de reales (BARREIRo FERnÁNDEZ, Xosé Ramón: «La burguesía compostelana: la familia «De Andrés García» (1760-1815)», en La ciudad y el mundo urbano en la Historia de Galicia, Santiago, 1988, p. 270).

90. Sobre su biografia, obras y proyectos principales, vid. la voz «Ferro Caaveiro, Lucas Antonio», en Gran Enciclopedia Gallega, Lugo, 1974, tm. XVII, pp. 177-181.

91. Tal y como ocurrió en los ayuntamientos murcianos (PÉREz PICAZO, $\mathrm{M}^{\mathrm{a}}$ Teresa: Las oligarquías municipales, op. cit., pp. 29-30; Oligarquías municipales, op. cit., pp. 62-64). Según esta autora, a la misma conclusión llegó J. P. JeSENNE en su trabajo sobre los efectos de la Revolución francesa en las comunas de Artois, titulado Pouvoir en village et Revolution. Artois, 1760-1848, Presses Universitaires de Lille, 1987. 
común. Se corrobora a la vista de la relación de cuotas asignadas para la contribución extraordinaria de guerra que se elaboró en septiembre de $1813^{92}$ : la mitad de ellos son hacendados, aunque no figuran entre los principales contribuyentes de la ciudad, salvo en el caso de Pedro $\mathrm{M}^{\mathrm{a}}$ Bermúdez, y la otra mitad es gente con ingresos pero inferiores, en su mayoría de procedencia letrada.

Como es sabido, la duración de los cargos era breve: cada año debían renovarse los alcaldes y la mitad de los concejales y procuradores, y allí donde lo permitía la población nadie podía ser reelegido antes de dos años ${ }^{93}$. Pues bien, a tenor de estas circunstancias, en Santiago se celebraron otras dos elecciones antes del restablecimiento del modelo antiguo (una en diciembre de 1812 y otra en diciembre de 1813), en cada una de las cuales entraron nueve individuos ${ }^{94}$. Entre los nuevos munícipes sigue habiendo algunos miembros de linajes conocidos de la ciudad, como los Vasadre, los Torre, los Valderrama o el conde de Maceda; éste último, en concreto, era oriundo de Ferrol, llevaba en ella pocos años y era su cuarto contribuyente más importante conforme a la mencionada relación de cuotas de guerra, por detrás del conde de Amarante, el arzobispo y el conde de Altamira, en cabeza por este orden. El resto en general parece ser de condición menos acaudalada que los de agosto de 1812, más si cabe los electos en el año 1813, pues entre ellos no figuran titulados ni grandes fortunas y por sus profesiones se refleja aún más claramente el acceso de los burgueses de clase media al gobierno local ${ }^{15}$.

Una nota común en las tres corporaciones es la proporción nada despreciable (entre un cuarto y un tercio) de los que intentan exonerarse del cargo, alegando las

92. AHUS: Municipal, LdC 1813, n 322 , ff. 207-252, conforme a la instrucción de 3 de septiembre de 1812 , donde localizamos al $90 \%$ de los electos en los tres comicios constitucionales celebrados. Sus cuotas anuales en reales de vellón eran las siguientes: el doctor don Joaquín Bernardo Flores, 2.340,2; Ido don Domingo Vales, 75 (?); don Francisco Montenegro 7.026,25 (+ 370 de asistencia hijo); don Francisco Xavier Losada, 2.813,8; don Julián Suárez Freire, 1.334,8; don Pedro Maria Bermúdez, 32.388,2 (+ 750 y 27,17 en asistencias); don Miguel Cotón, 843,31; doctor don Agustín Vales Vaamonde, 2.722,26; don José Ozores Villafane, 3.850; don Francisco Xavier de Gándara, 80,2; don Francisco Ferro Caaveiro, 75; don Agustín Frasmonte, 400; don Simón Pedrosa, 13.399,10; don José Calderón, conde de San Juan, $10.188,14$ ( $+633,31$ de asistencias); y don Anselmo Cabello, 409,14 sin las utilidades de su comercio, que se suponen muy superiores, pues era un adinerado burgués.

93. CASTRO, Concepción de: La revolución, op. cit., p. 70; SÁNCHEZ-ARCILLA BERNAL, José: Del municipio, op. cit., p. 657.

94. En la de diciembre de 1812: como alcaldes, don Andrés Vicente de Parga (primero) y don Manuel García Barros (segundo); como regidores, don Martín Fernández de Andrade, el conde de Maceda Juan José Caamaño, don diego María Vasadre, don Tomás Reguera, don José Camiño y don Angel Martínez de la Riba; y, como procurador, el abogado don Antonio Casal. Y en la del I de enero de 1814: los alcaldes don Jacobo Pastoriza (primero) y don Ramón Rey (segundo); los regidores don Manuel Mia Valderrama, don Silverio Moreno Ibáñez, don Basilio de Castro, don Diego Álvarez Martinez, don Julián Mourullo y el oficial retirado don Manuel $\mathrm{M}^{\text {u }}$ de la Torre; $\mathrm{y}$, como procurador, don Roque Jacinto Martínez (AHUS: Municipal, LdC de 1812, n³ 319, CO 2/12/1812, f. 426 y LdC 1814, n³24, CO $1 / 1 / 1814$, f. 19, respectivamente).

95. Lo mismo ocurrió en Alicante, según ÁlvAREZ y CAÑAS, Mª Luisa: El gobierno de la ciudad, op. cit., pp. 273-285. 
más diversas razones, que van desde la edad y enfermedad hasta la ocupación de sus propios trabajos, pasando por incompatibilidades varias como haber ejercido un oficio municipal antes y no tener pasado hueco de dos años, ser catedrático de leyes de la Universidad o bien ser oficial retirado. Ciertamente, cada vez en menor medida (de los comicios celebrados el 1 de enero de 1814 solo dos de los nueve). No en vano la Constitución concibe los empleos como una carga de la que «nadie podrá excusarse sin causa legal». De ahí que cuando uno no quiere ejercer el cargo busque acogerse a alguna incompatibilidad, aunque formalmente no fue aceptada ninguna. Claro que también hay quien opta por otra solución: tomar posesión del cargo y después no acudir al consistorio, como hizo el conde de Maceda, Juan José Caamaño, un claro defensor del absolutismo electo regidor en diciembre de 1812. Tanto es así que la corporación acabaría denunciándolo ante el jefe político por su reiterada inasistencia a pesar de estar en la ciudad, concretamente cuando le toca ser comisario del abasto público ${ }^{96}$.

Son algunos de los problemas que salpican la andadura del nuevo gobierno liberal en Santiago. En su caso, quizás porque era una ciudad esencialmente eclesiástica y eminentemente absolutista, incluso su burguesía estaba económicamente muy relacionada con las instituciones eclesiásticas, siendo su liberalismo de tono moderado ${ }^{97}$. Fuera por ello o por otras razones, evidencia también ciertas reservas o dificultades de un sector de los electos a colaborar con los nuevos ayuntamientos constitucionales. Se trata en su mayoría de miembros de la vieja o poderosa hidalguía, entre ellos algún militar retirado, pero también abogados, dos catedráticos de la Universidad y un burgués adinerado. Lo primero no sorprende, dada la actitud que las antiguas autoridades municipales mantuvieran frente a algunas disposiciones gaditanas, como el decreto de extinción de la Inquisición, al que se opusieron, solicitando ante las altas instancias su conservación $^{98}$. Claro que a las pocas semanas esas mismas autoridades hubieron de jurar la Constitución y un mes después trabajaban en la instauración del nuevo ayuntamiento constitucional, que se sepa el único establecido en la provincia de Santiago\%.

Por lo demás, durante los casi dos años que duró el régimen constitucional, se comenzaron a aplicar también las otras órdenes adoptadas en Cádiz que pretendían

96. AHUS: Municipal, LdC 1814, $\mathrm{n}^{\circ} 324, \mathrm{CO} 27 / 1 / 1814$, f. 117.

97. BARREIRo FernÁNDEZ, Xosé Ramón: Historia, op. cit, p. 141. Este autor señala además que la preterición de Santiago frente a la ciudad de A Coruña en la elección como capital de provincia, e incluso el que no se constituyera una quinta provincia en aquélla, fue una forma de premiar a la segunda, capital del liberalismo gallego, frente a la primera, cuna indudable del absolutismo ( $«$ De la tutela eclesiástica a los inicios de la andadura burguesa (1808-1875)», en PORTELA SILVA, Ermelindo (coord.): Historia de la ciudad de Santiago de Compostela, Santiago de Compostela, 2003, p. 450).

98. Como es sabido, la Iglesia compostelana hizo fuerza para oponerse a ello y en esa batalla le secundaron el resto de los obispos y cabildos gallegos, salvo el de Tuy de talante más liberal, y también algunos concejos como el de Santiago (AHUS: Municipal, LdC 1812, n³ 318, CO 27/5/1812, ff, 279, 295-296v; BarReIRo Fernández, Xosé Ramón: Historia, op. cit., pp. 148-153).

99. FARIÑa JAmARdo, Xosé: Os concellos galegos (Parte Xeral), A Coruña, 1990, p. 26. Como contraste, señala este autor, en la antigua provincia de de Tuy se habían formado setenta y siete (p. 27). 
modificar la sociedad y orden del Antiguo Régimen ${ }^{100}$. Simultáneamente, y como no podía ser de otra forma, persisten las divergencias y actitud hostil de las autoridades eclesiásticas hacia el nuevo régimen y sus instituciones, que arrancan ya del momento en que no fueron convocadas para las Cortes, continúa con la abolición de señoríos eclesiásticos y civiles y se agrava después con la supresión del Santo Oficio y extinción del voto de Santiago. Prueba de ello es que en las celebraciones del 2 de mayo de 1813, el cabildo eclesiástico se niega a «franquear» la capilla mayor de la Catedral a la corporación municipal, razón por la cual ésta solicita certificado de una provisión de 1607 inclusa en las Ordenanzas de la Real Audiencia de Galicia que, entre otras cosas, regulaba el protocolo a seguir (en cuanto a poner silla, banco, almohada y alfombra) en el supuesto de que los alcaldes mayores u oidores del Reino o bien alguno de ellos quisiera asistir a misa en su Capilla Mayor ${ }^{101}$.

Igualmente, se percibe el papel «omnipotente» que el nuevo régimen liberal otorga al jefe político o gobernador provincial, directamente nombrado por el gobierno, no sólo a nivel provincial (como máxima autoridad) sino también municipal. Al respecto, Galicia constituía una sola provincia con un único jefe político o jefe superior político que residía en A Coruña. Preside, por tanto, aquella corporación en tanto que la de Santiago lo está por el primer alcalde. Aun así, prácticamente nada escapa a su control, ya sea de forma directa o indirecta (Diputación provincial). En este sentido, esa tutela o presión es más evidente, si cabe, tras la destitución del marqués de Camposagrado, que fue amonestado por poner impedimentos a la formación de ayuntamientos en la provincia (Galicia) ${ }^{102}$. De hecho, a él correspondía no sólo dar cuenta de las órdenes superiores sino también velar por su acatamiento; así, por ejemplo, en lo tocante a las elecciones municipales era el encargado de que el proceso se ajustase a la legalidad, que los ciudadanos cumplieran con su derecho como electores y elegidos, resolviendo en última instancia (administrativa) las solicitudes de exoneración e incompatibilidad del cargo, e igualmente debía auxiliar a la corporación en el cumplimiento de sus competencias cuando ésta lo requieriese.

En todo caso, no será por mucho tiempo. Tras el regreso de Fernando VII, el curso de los acontecimientos políticos precipita el final del gobierno liberal, que se

100. Así, por ejemplo, en noviembre de 1812 se reciben copias de dos decretos, uno sobre la visita de cárceles por los eclesiásticos y otro relativo a la jurisdicción reconocida a los alcaldes constitucionales (mantienen determinadas competencias judiciales pero prevalece en ellos el componente gubernativo); a mediados de febrero del año siguiente serán los de abolición del voto de Santiago, administración de justicia por las Audiencias y jueces de primera instancia o colocación de magistrados y jueces de partido; y en julio llegan otros tres para que se quiten los signos de vasallaje que hubiese en la ciudad, empezando por el «rollo», amén de un cuarto sobre la presidencia de solemnidades y actos públicos AHUS: Municipal, LdC 1812, nº 319, CO 19/11/1812, f. 314-314v, 316-317; n 320, CO 15/2/1813, f. 206; 1" 321, ff. 373-374; CO10/7/1813, f. 341; CO 22/7/1813, f. 378v, etc.

101. Ibidem, $\mathrm{n}^{\circ} 321, \mathrm{CO} 4 / 5 / 1813$, f. 12v. La mencionada Real Provisión de 28 de marzo de 1607, que incluye dos autos del Consejo, puede verse en Ordenanzas de la Real Audiencia del Reino de Galicia, impresa en Coruña, por Antonio Frayz, 1679, f. 101-102.

102. AHUS: Municipal, LdC 1813, n³ 320, CO 22/4/1813, f. 448. 
materializa con la anulación de la Constitución y decretos aprobados por las Cortes (Real Decreto de 4 de mayo de 1814). El 17 de mayo se recibe la noticia oficial en Santiago ${ }^{103}$, hecho que la ciudad celebra con júbilo y fastos varios, detrás de los cuales se advierte una clara motivación política: se entiende que todo volvería a ser como antes, aunque no fuera exactamente así. Después se suceden las disposiciones para restablecer el viejo orden, que, lógicamente, también afectaron a la institución municipal. De hecho, ya el mismo día 4 de mayo se suprimieron los jefes políticos o jefes superiores políticos, transfiriendo sus competencias a los capitanes y comandantes generales, y el 16 se ordena continuar las autoridades y contribuciones en el estado que tenían antes de la ocupación. A principios de junio el arzobispo de Santiago regresa de su destierro y el 30 de de julio se dispone el restablecimiento de los ayuntamientos de 1808 , así como la supresión de las Diputaciones provinciales «por innecesarias» ${ }^{104}$. De esta forma queda cerrada la primera etapa del municipio constitucional y se inicia la primera restauración.

\section{EPÍLOGO: LA VUELTA AL MODELO ANTIGUO}

El 26 de agosto se recibe y da lectura en consistorio a la copia de la Real Cédula de 30 de junio que ordenaba disolver los ayuntamientos constitucionales y restablecer los de 1808, con los hombres que representaban el orden del Antiguo Régimen. Al día siguiente, en su cumplimiento, cesan los vocales que entonces formaban la corporación y se efectúa el reintegro a los antiguos, corporeizado en cinco regidores perpetuos, que son los que acuden por residir entonces en la ciudad. El proceso se completa convocando a los ausentes a que acudiesen para devolverles sus empleos, al tiempo que se celebran nuevas elecciones de los oficios anuales en que el titular y demás candidatos de antaño hubieran fallecido, tal y como ocurriera con el procurador del común ${ }^{105}$. En el caso de los oficios perpetuos, antes o después los titulares que entonces estaban en activo van acudiendo, excepto Francisco Javier Losada de Vivero que se excusa so pretexto de ejercer un oficio en el Consejo de Guerra. También lo hacen los dos alcaldes ordinarios, ambos colaboradores con el régimen liberal, disponiendo el Real Acuerdo que se celebrasen nuevas elecciones ${ }^{106}$. A raíz de ello se entabla un pequeño

103. Ibídem, $\mathrm{LdC} 1814, \mathrm{n}^{\circ} 325, \mathrm{CO} 17 / 5 / 1814$, ff. 448-449. En realidad, las instituciones de la ciudad rivalizan entre sí para ofrecer un gran espectáculo en honor al rey. Al respecto, véase LÓPEZ FERREIRO, Antonio: Historia, op. cit., pp. 270-277, y BARREIRO FERNÁNDEZ, Xosé Ramón: Historia, op. cit., pp. 159-163.

104. AHUS: Municipal, LdC 1814, n³ 325, CO 28/5/1814, ff. 482-483; CO 7/6/1814, f. 507; CO 2/7/1814, f. $541 \mathrm{v}$.

105. Ibidem, CO 26/8/1814, ff. 674 y 677; CO 27/8/1814, ff. 678-679v; CO 28/8/1814, f. 682 .

106. Ibidem, CO 29/8/1814, f. 686; CO 12/9/1814, f. 731-731v; CO 16/9/1814, f. 748-749; CO 16/9/1814, f. 748 ; $\mathrm{CO} 19 / 9 / 1814$, f. 757 ; $\mathrm{CO} 20 / 9 / 1814$, f. 765 y 761 ; CO 21/9/1814, f. 768 ; CO 28/9/1814, f. 798 ; CO 5/10/1814, ff. 813-813v; CO 11/10/1814, ff. 830-830v, 871 y 878 ; CO 12/10/1814, ff. 831-832v; CO $21 / 10 / 1814$, f. $871 \mathrm{v} ; \mathrm{CO} 24 / 10 / 1814$, f. 874 ; CO 28/10/1814, f. $878 ; n^{\circ} 326$, CO 10/11/1814, f. 911. 
contencioso entre esta institución, encargada de designar los dos alcaldes de una lista de propuestos, y el concejo, que confeccionaba dicha lista, sobre a quien competía otorgar la vara de alcalde más antiguo, pues aquél remitió el auto de nombramiento, consignando un alcalde primero y un alcalde segundo. La corporación protesta, aduciendo que esta diferencia había sido introducida por la abolida Constitución y que en la ciudad los dos alcaldes siempre fueran iguales, sin otra diferencia que la de denominarse «más o menos antiguo», teniendo el primero preferencia de voto y ciertas preeminencias, pero que el hacer dicha distinción correspondía en exclusiva al regidor decano, que solía atribuirla por «predilección de cuerpo, deudo, trato, amistad u otra honesta consideración $\rangle^{107}$. Ignoro cómo se resolvió el asunto, aunque todo indica que se respetó el derecho consistorial.

Añadiré, y con ello concluyo, que con la restauración del orden absolutista tradicional los ediles municipales recuperaron también sus privilegios, incluido el de estar exentos de alojamientos ${ }^{108}$. Claro que también reaparecieron parte (o una buena parte) de los problemas y lacras que antaño padecía el ayuntamiento y su clase dirigente. Hablo, por ejemplo, del absentismo capitular, siendo así que ya a mediados de noviembre del mismo año 1814 la corporación compostelana se hace eco de ello, habida cuenta del escaso número de regidores que asistía a las sesiones consistoriales y del mucho trabajo acumulado, instando a los ausentes a concurrir a desempeñar sus oficios y a quienes los tenían vacantes que los proveyeran bajo ciertas penas; incluso se les amenaza con tomar medidas más drásticas ${ }^{109}$. Pero suena a letra muerta, igual que en tantas otras ocasiones, pues el problema no tenía fácil solución mientras los regimientos siguieran siendo como antes perpetuos.

107. Ibidem, n³25, CO 12/10/1814, f. $917 ; \mathrm{n}^{\circ} 326$, CO 12/11/1814, ff. 917-918.

108. Ibidem, CO 24/12/1814, f. 1032.

109. Ibidem, CO 14/11/1814, f. 1001. 